\title{
Genetic variation in Heterobasidion abietinum populations detected with the M13 minisatellite marker
}

\author{
By L. Zamponi ${ }^{1}$, D. Paffetti $^{2}$, S. Tegli ${ }^{1}$, P. Łakomy ${ }^{3}$ and P. Capretti ${ }^{1,4}$ \\ ${ }^{1}$ Department of Agricultural Biotechnology, University of Florence, Piazzale delle Cascine, Florence, \\ Italy; ${ }^{2}$ Department of Environmental and Forestry Technologies and Sciences, University of Florence, \\ Florence, Italy; ${ }^{3}$ Department of Forest Pathology, Agricultural University Ul. Wojska Polskiego 71c, \\ Poznan, Poland. ${ }^{4}$ E-mail: paolo.capretti@unifi.it (for correspondence)
}

\begin{abstract}
Summary
Amplification profiles of the M13 minisatellite core sequence from 47 isolates of Heterobasidion annosum s.l., collected mostly from Abies alba in different European countries, were analysed in comparison with profiles of four isolates of $H$. annosum s.s. and three isolates of $H$. parviporum. Genetic variation within and among groups of populations was studied by analysis of molecular variance. A dendrogram constructed with the Neighbor-Joining method differentiated the three species from each other. Isolates of $H$. abietinum from Balkan peninsula, Italian peninsula and French Pyrenees each separated into clusters according to geographical origin. Such clear geographic clustering was not detected among isolates from central Europe. The variations between $H$. abietinum isolates in relation to the migration history of Abies are discussed.
\end{abstract}

\section{Introduction}

Heterobasidion abietinum Niemelä \& Korhonen (the 'F type' of $H$. annosum s.l.) is a root rot fungus with a distribution area predominantly in the south of Europe, with main hosts in the genus Abies. The known distribution of the fungus extends to Spain in the west, to southern Poland in the north, to the western Caucasus in the east and to southern Greece and Italy in the south (WoOdward et al. 1998; Korhonen and Dai 2005; SÁnchez et al. 2005). Root and butt rot caused by $H$. abietinum is economically important in forests of $A$. alba in Italy and of A. cephalonica and A. borisii-regis in Greece, where Abies spp. are under stress from the dry summer climate (KorHonen et al. 1998). In central Europe and the Pyrenees, where summers are more humid, $H$. abietinum is mostly a saprophyte on the stumps and logs of Abies, and has only minor economic importance (Munda 1994; ŁaKOMY 1996).

The distribution of $H$. abietinum in Europe is more restricted than that of $H$. annosum s.s. and $H$. parviporum. It is likely that $H$. abietinum is limited to Europe, including neighbouring regions in the Middle East and northern Africa, where the western Eurasian species of Abies occur (DAI et al. 2003; DoĞmuş-LehtijäRvi et al. 2006).

Hitherto, the different geographical populations of $H$. abietinum were studied only by LA PORTA et al. (1997), in an investigation dealing with $H$. abietinum in Italy alone. Analysis of randomly amplified polymorphic DNA (RAPD) markers of $H$. abietinum isolates from a number of sites suggested that the isolates tended to group at the level of the larger geographical areas. Isolates from southern Italy showed the greatest genetic variation, while the northern isolates (from the Alpine regions) showed the least.

The present study examined populations of $H$. abietinum from different parts of Europe by analysing profiles obtained following direct amplification of minisatellite DNA-PCR 
(DAMD-PCR), using the minisatellite M13 as a primer. This method was previously applied to studies of Heterobasidion by STENLID et al. (1994), and also to examine the geographical differentiation of other fungal populations such as Ceratocystis platani, Ophiostoma ulmi and Nectria fuckeliana (Vasiliauskas and STENlid 1997, 1998; Hogberg and Stenlid 1999; Hogberg et al. 1999; Santini and Capretti 2000; Santini et al. 2005). The aim of this work was to determine if the genetic variation of $H$. abietinum isolates sampled in the Mediterranean basin and in central Europe presented a geographical structure. Any such geographical structure may be connected with the migration history of A. alba, the main host of $H$. abietinum.

\section{Materials and methods}

Forty-seven isolates (38 homokaryotic and nine heterokaryotic) were examined: 40 of $H$. abietinum, four of $H$. annosum s.s. and three of $H$. parviporum (Table 1). H. abietinum isolates came from different geographical regions: central Europe (Poland, Austria, Switzerland), the Italian peninsula, the Balkan peninsula (Greece, Bulgaria, Slovenia) and French Pyrenees. The four $H$. annosum s.s. isolates were from Austria and the three $H$. parviporum isolates from Austria (one) and Poland (two). These last two species were included in the test for comparison.

\subsection{DNA extraction and amplification}

Isolates were grown in $2.4 \%$ potato dextrose broth (PDB). After 2 weeks of incubation at $23^{\circ} \mathrm{C}$ mycelium was collected on filter paper by vacuum filtration. DNA was extracted using the procedure of SMITH and STANOsZ (1995). Amplification profiles were obtained in PCR experiments using the M13 minisatellite core sequence (5'-AGGGTGGCGGTTCT3'; Innovagen, Lund, Sweden; KarLsson 1993). Amplifications were performed in volumes of $25 \mu$ containing: Tris-HCl 10 mm, pH 8; dNTPS $0.2 \mathrm{~mm}$; $\mathrm{MgCl}_{2} 2.5 \mathrm{~mm}$; Taq $1 \mathrm{U} / \mu \mathrm{l}$; minisatellite M13 $12.7 \mu \mathrm{M} ; 20 \mathrm{ng}$ of fungal DNA. The thermal cycler was programmed for a predenaturation step at $93^{\circ} \mathrm{C}$ for $3 \mathrm{~min}$, followed by 45 cycles at $93^{\circ} \mathrm{C}$ for $1 \mathrm{~min}, 55^{\circ} \mathrm{C}$ for $1 \mathrm{~min}, 72^{\circ} \mathrm{C}$ for $1 \mathrm{~min}$ and a final extension at $72^{\circ} \mathrm{C}$ for $10 \mathrm{~min}$.

About $8 \mu \mathrm{l}$ of each amplification product was loaded into $1.4 \%$ agarose gel with TBE buffer (40 mm Tris-borate, $1 \mathrm{~mm}$ EDTA, $\mathrm{pH} 8$ ) and $0.5 \mu \mathrm{g} / \mathrm{ml}$ ethidium bromide. Electrophoresis was carried out at $90 \mathrm{~V}$ for $2.5 \mathrm{~h}$. Gels were visualized through UV fluorescence and photographed; the molecular size of the amplification products was estimated by comparison with the marker $1 \mathrm{~kb}$ plus DNA ladder (GIBCO BRL, Life Technologies, Gaithersburg, MD, USA).

\subsection{Statistical data analysis}

Analysis of molecular variance (AMOva) was used to assess the partitioning of the genetic variance among different groups, and populations (ExCOFFIER et al. 1992) using the program ARLEQUIN 2.000 (SCHNEIDER et al. 1997). AMOva divides the total variance into hierarchical partitions, among groups, among populations within groups and within populations. A test of permutation computes the statistical significance of each partition. The analyses were performed on haplotype frequencies only and for each analysis, 16000 permutations were computed to obtain the significance levels of the variance.

A vector of presence/absence of M13 minisatellite markers was used to compute, with the Euclidean metric measurement, the matrix of genetic distances for each pair of isolates. AMOva procedure was used to estimate the variance components of M13 profiles, and to partition the variation among and within groups. 
Table 1. Isolates tested using M13 minisatellite

\begin{tabular}{|c|c|c|c|c|}
\hline Isolate & Code & Species & Host & Geographical origin \\
\hline Pyr-5 & 970907 5.2.2. & H. $a b$. & Abies alba & Aucun, Pyrenees, France \\
\hline Pyr-7 & 990219 & H. $a b$. & Abies alba & Airege, Pyrenees, France \\
\hline Fr-1 & Del1 & H. $a b$. & Pinus sylvestris & France \\
\hline Fr-3 & $951025 \mathrm{H} 80$ & H. $a b$. & Abies grandis & Amance, France \\
\hline Fr-4 & 951015 H81 & H. $a b$. & Abies alba & Vosges, France \\
\hline Fr-6 & $951130 \mathrm{H} 82$ & $H . a b$. & Cedrus atlantica & France \\
\hline Fr-7 & $951130 \mathrm{H} 84$ & $H . a b$. & Pseudotsuga menziesii & France \\
\hline It-1 & $9204012 \mathrm{ve}$ & H. $a b .^{1}$ & Pseudotsuga menziesii & Vellano (PT), Italy \\
\hline It-2 & $9204013 \mathrm{ve}$ & H. $a b .^{1}$ & Pseudotsuga menziesii & Vellano (PT), Italy \\
\hline It-3 & 9310073.1 & H. $a b$. & Abies alba & Valgrande (BL), Italy \\
\hline It-9 & $9508101.1 \mathrm{ve}$ & H. $a b .^{1}$ & Abies alba & Molveno (TN), Italy \\
\hline It-14 & 9310304.33 & H. $a b$. & Pinus nigra & Serra San Bruno (VV), Italy \\
\hline It-15 & 9309211.4 & H. $a b$. & Abies alba & Metato (FI), Italy \\
\hline It-16 & 9109107.1 & H. $a b$. & Abies alba & Vallombrosa (FI), Italy \\
\hline Gr-1 & HL-2.1 & H. $a b$. & Abies cephalonica & Parnon mountain, Greece \\
\hline Gr-2 & HT-4 & $H . a b$. & Abies cephalonica & Taygetos mountain, Greece \\
\hline Gr-3 & HT-8 & H. $a b$. & Abies cephalonica & Taygetos mountain, Greece \\
\hline $\mathrm{Gr}-4$ & $\mathrm{He}-1$ & H. $a b$. & Abies cephalonica & Helikon mountain, Greece \\
\hline Ch-5 & 950328.16 & H. $a b$. & Abies alba & Zollikon, Switzerland \\
\hline Ch-6 & 951218.1 & H. $a b$. & Abies alba & Forch, Switzerland \\
\hline Ch-7 & 951225.5 & H. $a b$. & Abies alba & Forch, Switzerland \\
\hline Sl-1 & $9210 / 4.2$ & H. $a b$. & Abies alba & Sneznik, Slovenia \\
\hline Sl-4 & $9304 / 1.1$ & $H . a b$. & Picea abies & Trnovski, Slovenia \\
\hline Pol-3 & 20029 & H. $a b$. & Abies alba & Limanowa, Poland \\
\hline Pol-4 & 20039 & H. $a b .^{1}$ & Abies alba & Siemianice, Poland \\
\hline Pol-7 & 20049 & H. $a b^{1}$ & Abies alba & Poland \\
\hline Pol-9 & 20053 & H. $a b .^{1}$ & Abies alba & Roztoczaski National Park, Poland \\
\hline Pol-11 & 97006 & H. $a b .^{1}$ & Abies alba & Ojcowski National Park, Poland \\
\hline Bul-1 & 95265.5 & $H . a b$. & Abies alba & Pirin Mountain, Bulgaria \\
\hline Bul-3 & 95269.6 & H. $a b$. & Abies alba & Pirin Mountain, Bulgaria \\
\hline Bul-4 & 95270.1 & H. $a b$. & Abies alba & Pirin Mountain, Bulgaria \\
\hline Bul-5 & 95271.4 & H. $a b$. & Abies alba & Pirin Mountain, Bulgaria \\
\hline Bul-7 & 95282.1 & H. $a b$. & Abies alba & Pirin Mountain, Bulgaria \\
\hline Bul-8 & 95284.2 & H. $a b$. & Abies alba & Pirin Mountain, Bulgaria \\
\hline $\mathrm{Au}-4$ & 9511151.4 & H. $a b$. & Picea abies & Klein Krottenbachtal, Austria \\
\hline $\mathrm{Au}-5$ & 9511151.5 & H. $a b$. & Picea abies & Klein Krottenbachtal, Austria \\
\hline $\mathrm{Au}-8$ & 9511152.3 & H. $a b$. & Picea abies & Hensgstpass, Austria \\
\hline Au-9 & 9511152.4 & H. $a b$. & Picea abies & Hensgstpass, Austria \\
\hline $\mathrm{Au}-10$ & 9511152.5 & H. $a b$. & Picea abies & Hensgstpass, Austria \\
\hline Au-14 & 9511153.2 & H. $a b$. & Picea abies & Hensgstpass, Austria \\
\hline Pol-1 & 20021 & $H . p .^{1}$ & Picea abies & Suwaki, Poland \\
\hline Pol-6 & 20048 & H. p. ${ }^{1}$ & Abies alba & Limanowa, Poland \\
\hline $\mathrm{Au}-26$ & 9511157.2 & H. $p$ & Picea abies & Paudorf, Austria \\
\hline $\mathrm{Au}-21$ & 9511154.3 & H. a. & Pinus sylvestris & Gars Fiecher, Austria \\
\hline $\mathrm{Au}-24$ & 9511156.1 & H. a. & Pinus nigra & Schonberg, Austria \\
\hline $\mathrm{Au}-25$ & 9511156.2 & H. a. & Larix decidua & Schonberg, Austria \\
\hline $\mathrm{Au}-30$ & 9511158.1 & H. a. & Pinus sylvestris & Paudorf, Austria \\
\hline \multicolumn{5}{|c|}{$\begin{array}{l}\text { H. ab. = Heterobasidion abietinum; H. p. = Heterobasidion parviporum; H. a. = Heterobasidion } \\
\text { annosum s.s. } \\
{ }^{1} \text { Heterokaryotic isolates. }\end{array}$} \\
\hline
\end{tabular}

A dendrogram was constructed using Nei and Li genetic distance (NeI and Li 1979) with Neighbor-Joining method (SAITOU and NeI 1987). Analyses were conducted using PHYLOGENY INFERENCE PACKAGE software (FELSENSTEIN 1993). The robustness of the inferred tree was evaluated by 500 bootstrap re-samplings. 


\section{Results}

The electrophoretic profiles of the amplification products (Table 2) yielded a total of 32 markers with molecular weights between 300 and $12000 \mathrm{bp}$, some of which were specific for one of the three Heterobasidion species. Some isolates of $H$. abietinum

Table 2. Presence-absence (1/0) vector of Heterobasidion s.l. isolates tested with the M13 primer

\begin{tabular}{|c|c|}
\hline H. ab. Pyr-5 & 00000001001000000000110000000000 \\
\hline H. ab. Pyr-7 & 00000001001010000010100000000000 \\
\hline H. ab. Fr-1 & 00000001101010000010100000000000 \\
\hline H. $a b . \mathrm{Fr}-3$ & 00001001001000000010100000000000 \\
\hline H. $a b . \mathrm{Fr}-4$ & 00001001001000000010100000000000 \\
\hline H. $a b . \mathrm{Fr}-6$ & 00001001001000000000100000000000 \\
\hline H. $a b . \mathrm{Fr}-7$ & 00001001001010000000100000000000 \\
\hline H. $a b$. It-3 & 00001001001000000000100001010011 \\
\hline H. $a b . \mathrm{It}-1$ & 00000001001000000000100001010001 \\
\hline H. ab. It-2 & 00000001001000000000100001010001 \\
\hline H. $a b$. It -9 & 00000101001000000000100001010001 \\
\hline H. $a b$. It-14 & 00000101001000000000100001010001 \\
\hline H. $a b . \mathrm{It}-15$ & 00000101001000000000100001010001 \\
\hline H. $a b$. It-16 & 00000101001000000000100101010001 \\
\hline H. $a b . \mathrm{Gr}-1$ & 01000001010000000111101000000000 \\
\hline H. $a b . \mathrm{Gr}-2$ & 01001001010000000111101000000000 \\
\hline H. $a b . \mathrm{Gr}-3$ & 01001001010000000111101000000000 \\
\hline H. $a b . \mathrm{Gr}-4$ & 01000001010000000111101001000000 \\
\hline H. $a b . \mathrm{Au}-4$ & 00000001000000000010100010000000 \\
\hline H. $a b . \mathrm{Au}-5$ & 00000001001000001000100000000000 \\
\hline H. $a b . \mathrm{Au}-8$ & 00000001000000001100100000000000 \\
\hline H. ab. Au-9 & 00000001000000001110110010110111 \\
\hline H. ab. Au-10 & 00000001000000001110100010001010 \\
\hline H. ab. Au-14 & 00000101000000001110100010000000 \\
\hline H. ab. Ch-5 & 00000101000000001000100100000001 \\
\hline H. $a b . \mathrm{Ch}-6$ & 00001101001100101000100000000000 \\
\hline H. $a b . \mathrm{Ch}-7$ & 00001001001100001000100100000000 \\
\hline H. $a b . \mathrm{Sl}-1$ & 00000001001001101000100101000000 \\
\hline H. $a b . \mathrm{Sl}-4$ & 00000001001001001110110101000000 \\
\hline H. $a b$. Pol-3 & 00001001000100000000100000000000 \\
\hline H. $a b$. Pol-4 & 00001101000100000000100000000001 \\
\hline H. $a b$. Pol-7 & 00001001000100000000100000000000 \\
\hline H. ab. Pol-9 & 00001111010100000000100000000000 \\
\hline H. ab. Pol-11 & 00001001010100000000100000000000 \\
\hline H. ab. Bul-1 & 00001001010000000110101000000000 \\
\hline H. $a b$. Bul-3 & 00000001010000000110101000000000 \\
\hline H. ab. Bul-4 & 00001001010000000110101000000000 \\
\hline H. ab. Bul-5 & 00001001010000000110101000000000 \\
\hline H. ab. Bul-7 & 00001001010000000110101000000000 \\
\hline H. ab. Bul-8 & 00001001010000000110101000000000 \\
\hline H. p. Pol-1 & 10001011000100000100000000000000 \\
\hline H. p. Pol-6 & 10001001000100000100000000000000 \\
\hline H. p. Au-26 & 10001001000100101100010000000000 \\
\hline H. a. Au-21 & 00111011000000111100000000000000 \\
\hline H. a. Au-24 & 00110011000100110100000000000000 \\
\hline H. a. Au-25 & 00010011000000110100000000011100 \\
\hline H. a. Au-30 & 00111011000100110100000000001000 \\
\hline
\end{tabular}


Table 3. Results of analysis of molecular variance (AMOVA) showing the geographic distribution on the genetic variation of Heterobasidion abietinum: (a) AMOVA among four geographic regions (Italian peninsula, Balkan peninsula, central Europe and French Pyrenees); (b) AMOVA among four geographic regions (Italian peninsula, Balkan peninsula and French Pyrenees)

\begin{tabular}{|lccc|}
\hline Source of variation & Variance components & Percentage of variation & p-Value \\
\hline a) Among groups & & & \\
Among populations within groups & 1.3 & 35.1 & 0.001 \\
Within populations & 1.2 & 32.9 & 0.001 \\
b) & 1.2 & 32.0 & 0.001 \\
Among groups & 2.1 & 55.4 & 0.001 \\
Among populations within groups & 0.9 & 25.0 & 0.001 \\
Within populations & 0.7 & 19.6 & 0.001 \\
\hline
\end{tabular}

showed identical banding patterns, but the profiles of the $H$. parviporum and $H$. annosum isolates all differed from each other. All isolates of $H$. abietinum had one marker in common; other markers were shared among isolates. The four isolates of $H$. annosum and the three isolates of $H$. parviporum had six and five monomorphic markers, respectively, although only small numbers of $H$. annosum and $H$. parviporum isolates were tested.

The Neighbor-Joining dendrogram (Fig. 1) separated isolates of the three Heterobasidion species into clusters. Isolates of $H$. abietinum were separated significantly from isolates of $H$. annosum and $H$. parviporum in the dendrogram. Isolates of $H$. abietinum clustered according to geographical origin, with the exception of those collected in the central Europe.

Analysis of molecular variance of the 40 isolates of $H$. abietinum collected in different geographical regions indicated that the percentage of genetic variation of this pathogen among four regions (Italian peninsula, Balkan peninsula, central Europe and French Pyrenees) was $35.1(\mathrm{p}<0.001)$ with $\Phi_{\text {st }}=68 \%$, Table 3 .

The dendrogram (Fig. 1) separated isolates from three parts of the Mediterranean basin: the Balkan peninsula, the Italian peninsula and the French Pyrenees, distinct clusters. Differences between these clusters, calculated with AMOva, were significant $(p<0.001)$ and the percentage of genetic variation among these groups was 55.4 whit $\Phi_{\text {st }}=80 \%$. In contrast, the percentage of variation within group among populations and within populations increased to 25.0 and 19.6 ( $\mathrm{p}<0.001$ ), respectively.

Isolates of $H$. abietinum collected in central Europe (Fig. 1) differed, however, constituting small clusters dispersed among and within the other three principal groups.

\section{Discussion}

The capacity of the M13 minisatellite as a primer to detect both isolate-specific and speciesspecific differences in Heterobasidion (STENLID et al. 1994) was confirmed. It was also found, consistent with KARLSSON (1993) that Neighbor-Joining clustering based on the M13 minisatellite profiles usually grouped the isolates according to geographic origin. Heterobasidion abietinum isolates collected from the Italian peninsula, Balkan peninsula and the French Pyrenees exhibited greater variation among regions (55.4\%) than within populations (16.6.\%). Similar results were reported by STENLID et al. (1994), who investigated genetic variations in local populations of $H$. annosum and $H$. parviporum collected at a certain distance from each other. LA PORTA et al. (1997) demonstrated that the variations between the Italian and north-European populations of $H$. parviporum were $71.1 \%$. 


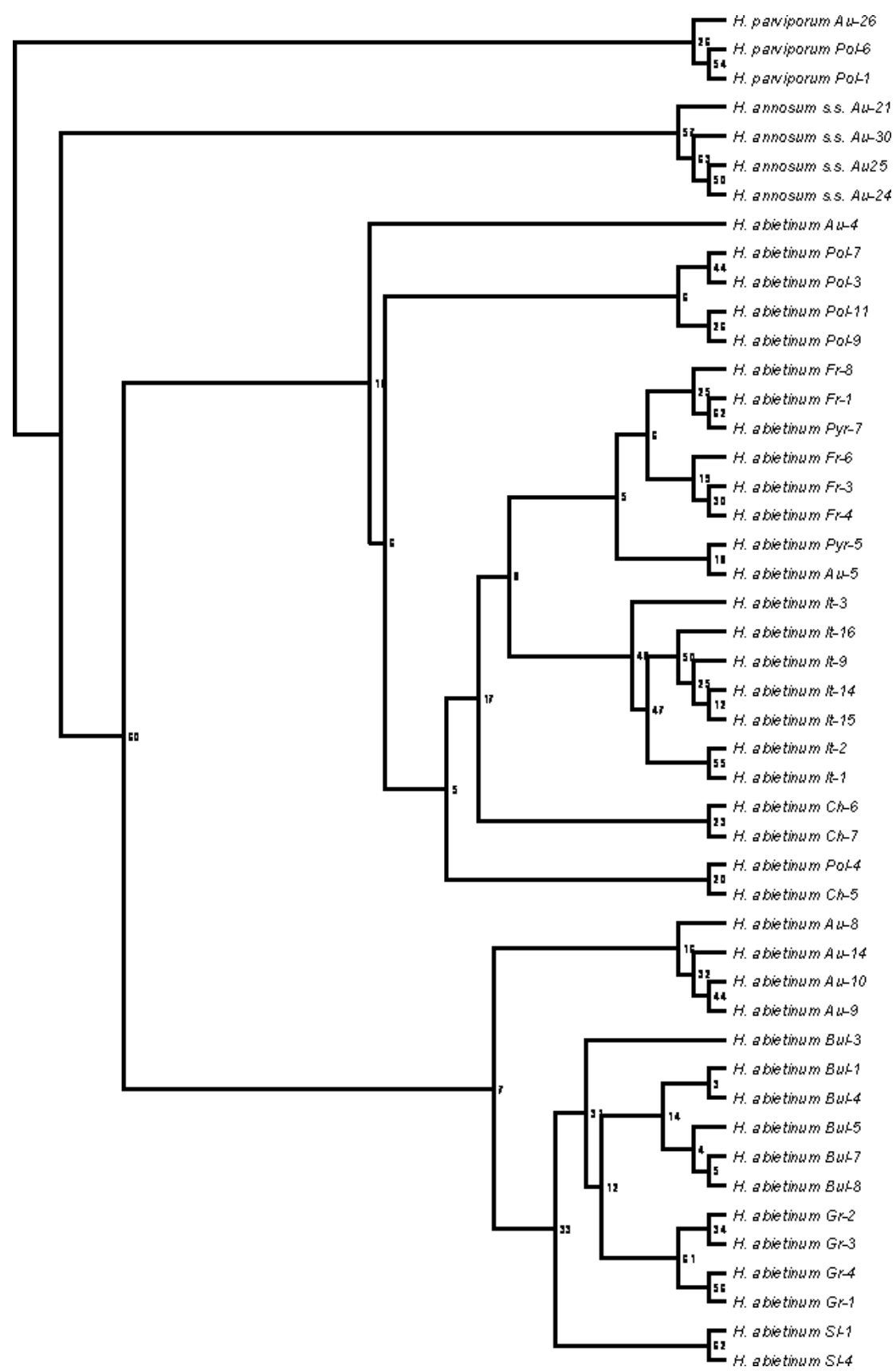

Fig. 1. Neighbor-Joining dendrogram for 47 European isolates of Heterobasidion annosum, $H$. abietinum and $H$. parviporum. Amplification profiles were obtained from PCR using the M13 minisatellite core sequence (for list of isolates see Table 1) 
In the present study, limited genetic flow between populations was apparently due to the long distances between the regions; as a result, each population varied independently from the others, modifying its genetic heritage. The lack of variation found between individuals in a given geographical region may also have been due in part to the fact that the collection sites were not randomly distributed throughout the regions. Living spores of Heterobasidion may be dispersed in air for hundreds of kilometres, but the great majority of spores fall within a hundred or a few hundred metres of the spore source (REDFERN and STENLID 1998); hence, even relatively narrow geographic barriers may lead to populations of Heterobasidion becoming diversified.

A diversification into ecotypes similar to that found with Heterobasidion can also be seen in populations of the host tree $A$. alba: different ecotypes grow in the Apennines and in the Pyrenees (Parducci et al. 1996; Ziegenhagen et al. 1998). In the Alps and central Europe, where $A$. alba does not differentiate into ecotypes in this way, the differentiation of $H$. abietinum is also only slight. This may explain why differences between isolates were greater than differences between populations.

During the last Glacial age, Italy, the Pyrenees and the Balkan region were important refugia for many tree species, including Abies, Picea and Pinus. Populations of Abies survived in the Dinaric Alps, the Carpathian Mountains and southern Russia (Miller 1977; BernetTi 1998). Abies alba found refuge in Calabria (southern Italy), the Balkan region and the Pyrenees. When the continental ice sheet began to retreat again, Pinus was the first dominant conifer genus to advance outward into the wider Mediterranean area, where it achieved a large but fragmented distribution. Picea abies began to spread somewhat later, and $A$. alba later still. Northward migration enabled Abies species to recolonize their present natural distribution, with a west to east migration in the Alps. The present distribution of $A$. alba in central Europe is due to spread of the Italian populations (BERNETTI 1998), resulting in an absence of $A$. alba ecotypes and pathogen variation in the Alps and central Europe.

The relatively large genetic distances between $H$. abietinum populations in the Italian peninsula, the Greek peninsula and the Pyrenees underline the scarce gene flow between these regions and probably reflect the diversification that took place in both the pathogen and the host trees that grew in the refuge areas during the last ice age. The Abies forests in the Alps and central Europe are a more uniform population as regards both the host tree, $A$. alba, and its companion, $H$. abietinum.

\section{Acknowledgements}

The authors are very grateful to Dr Kari Korhonen for comments and suggestions, and for kindly reviewing the manuscript.

\section{References}

BernetTI, G., 1998: Selvicoltura speciale. Torino, Italy: UTET, 415 pp.

Dai, Y.-C.; Vainio, E. J.; Hantula, J.; Niemelä, T.; Korhonen, K., 2003: Investigations on Heterobasidion annosum s.l. in central and eastern Asia with the aid of mating tests and DNA fingerprinting. For. Pathol. 33, 269-286.

DoĞmuş-Lehtijärni, H. T.; Lehtijärvi, A.; Korhonen, K., 2006: Heterobasidion abietinum on Abies species in western Turkey. For. Pathol. 36, 280-286.

Excoffier, L.; Smouse, P.; QuatTro, J., 1992: Analysis of molecular variance inferred from metric distances among DNA haplotypes: applications to human mitochondrial DNA restriction data. Genetics 131, 479-491.

Felsenstein, J., 1993: PHYLIP (Phylogen Inference Package), version 3.5c. Seattle: Department of Genetics, University of Washington (distributed by the authors). 
Hogberg, N.; Stenlid, J., 1999: Population genetics of Fomitopsis rosea - a wood-decay fungus of the old - growth European taiga. Mol. Ecol. 8, 703-710.

Hogberg, N.; Holdenrieder, O.; Stenlid, J., 1999: Population structure of the wood decay fungus Fomitopsis pinicola. Heredity 83, 354-360.

Karlsson, J.-O., 1993: Genetic variation in Heterobasidion annosum detected with M13 fingerprinting and ribosomal DNA probes. Exp. Mycol. 18, 48-56.

Korhonen, K.; DAI, Y.-C., 2005: Genetically identified taxa of Heterobasidion and their distribution in Eurasia. In: Proc. 11th Int. Conf. Root and Butt Rots. Ed. by Manka, M.; Łakomy, P., pp. $57-63$.

Korhonen, K.; Capretti, P.; Karjalainen, R.; Stenlid, J., 1998: Distribution of Heterobasidion annosum intersterility groups in Europe. In: Heterobasidion annosum. Biology, Ecology, Impact and Control. Ed. by Woodward, S.; Stenlid, J.; Karjalinen, R.; Huttermann, A. Oxon: C.A.B. International, pp. 93-104.

La Porta, N.; Capretti, P.; Kammiovirta, K.; Korhonen, K.; Karjalainen, R., 1997: The relatedness of the Italian $\mathrm{F}$ intersterility group of Heterobasidion annosum with the $\mathrm{S}$ group, as revealed by RAPD assay. Mycol. Res. 101, 1065-1072.

Łлкому, P., 1996: F group of Heterobasidion annosum found in Poland. Eur. J. For. Path. 26, $217-222$.

Miller, C. N., 1977: Mesozoic conifers. Bot. Rev. 43, 217-280.

Munda, A., 1994: Preliminary report on the distribution of Heterobasidion annosum intersterility groups in Slovenia. In: Proc. 8th Int. Conf. Root and Butt Rots, Wik, Sweden and Haikko, Finland. 9-16 August 1993. Ed. by Johansson, M.; Stenlid, J. Uppsala: Swed. Univ. Agric. Sci., pp. 272 273.

NeI, M.; LI, W. H., 1979: Mathematical model for studying genetic variation in terms of restriction endonucleases. PNAS 76, 5269-5273.

Parducci, L.; Szmidt, A. E.; Villani, F.; Wang, X. R.; Cherubini, M., 1996: Genetic variation of Abies alba in Italy. Hereditas 125, 11-18.

Redfern, D. B.; Stenlid, J., 1998: Spore dispersal and infection. In: Heterobasidion annosum. Biology, Ecology, Impact and Control. Ed. by Woodward, S.; Stenlid, J.; Karjalinen, R.; Huttermann, A. Oxon: C.A.B. International, pp. 105-124.

Sánchez, M. F.; Capretti, P.; Calzado, C.; Navarro, R.; Trapero, A., 2005: Root rot disease on Abies pinsapo in southern Spain. In: Proc. 11th Int. Conf. Root and Butt Rots. Ed. by Manka, M.; ŁAKOMY, P., pp. 220-223.

Saitou, N.; NeI, M., 1987: The neighbor-joining method: a new method for reconstructing phylogenetic trees. Mol. Biol. Evol. 4, 406-425.

Santini, A.; Capretti, P., 2000: Analysis of the Italian population of Ceratocystis fimbriata f.sp. platani using RAPD and minisatellite markers. Plant Pathol. 49, 461-467.

Santini, A.; Montaghi, A.; Vendramin, G. G.; Capretti, P., 2005: Analysis of the Italian Dutch Elm Disease Fungal population. J. Phytopathol. 153, 1-7.

Schneider, S.; Kueffer, J. M.; Roessli, D.; Excoffier, L., 1997: Arlequin ver 1.1: a Software for Population Genetic Data Analysis. Switzerland: Genetics and Biometry Laboratory, University of Geneva.

Smith, D. R.; Stanosz, G. R., 1995: Confirmation of two distinct populations of Sphaeropsis sapinea by in the North Central United States using RAPDs. Phytopathology 85, 699-704.

Stenlid, J.; Karlsson, J.-O.; Hogberg, N., 1994: Intraspecific genetic variation in Heterobasidion annosum revealed by amplification of mini satellite DNA. Mycol. Res. 98, 57-63.

Vasiliauskas, R.; STENlid, J., 1997: Population structure and genetic variation in Nectria fuckeliana. Can. J. Bot. 75, 1707-1713.

VAsiliauskas, R.; STEnlid, J., 1998: Population structure and genetic variation in Cilindrobasidion evolvens. Mycol. Res. 102, 1453-1458.

Woodward, S.; Stenlid, J.; Karjalainen, R.; Hütterman, A., 1998: Heterobasidion annosum. In: Biology, Ecology, Impact and Control. Ed. by Woodward, S.; STEnlid, J.; Karjalinen, R.; Huttermann, A. Oxon: C.A.B. International, 589 pp.

Ziegenhagen, B.; Scholz, F.; Madaghiele, A.; Vendramin, G. G., 1998: Hypervariable chloroplast microsatellites as markers for paternity analysis in Abies alba. Can. J. For. Res. 28, 317-321. 